\title{
Soil Available Zinc and Its Relationship with Soil Properties in Rice Soils of West Bengal, India
}

\author{
Umalaxmi Thingujam $^{1 *}$, Dipa Kundu ${ }^{1}$, Rubina Khanam², \\ Sudeshna Mondal ${ }^{1}$ and G.C. Hazra ${ }^{1}$ \\ ${ }^{1}$ Department of Agricultural Chemistry and Soil Science, Bidhan Chandra Krishi \\ Viswavidyalaya, Mohanpur, West Bengal, India \\ ${ }^{2}$ ICAR-National Rice Research Institute, Cuttack, Odisha, India \\ *Corresponding author
}

\section{A B S T R A C T}

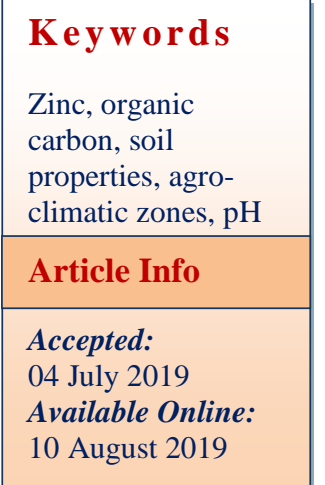

\section{Introduction}

Zinc $(\mathrm{Zn})$ deficiency is the most widespread micronutrient deficiency problem resulting in reduced crop production and nutritional quality of edible plant parts (Cakmak, 2002). It has also been reported in almost all countries (Alloway, 2008) including India in different soil types (Shukla et al., 2014). It is commonly prevalent in highly leached, heavily weathered and sandy acid soils with low organic matter content (Rautaray et al., 2003). Rice (Oryza sativa L.) is one of highly sensitive crops to zinc ( $\mathrm{Zn}$ ) deficiency; $\mathrm{Zn}$ is the most important micronutrient limiting rice growth and yield (Alloway, 2004; Dong et al., 2006). The availability of $\mathrm{Zn}$ in the soil varies widely depending on the soil properties and is associated with many soils and environmental factors which affect its availability to crop. The major factors which are responsible for zinc deficiency includes alkaline calcareous soil, sandy texture, low organic matter, high 
$\mathrm{pH}$, use of high analysis NPK fertilizer, high yielding genotypes etc (Cakmak, 1998; Anonymous, 1998; Tandon, 1995; Mortvedt et al., 1991). Availability of micronutrients including $\mathrm{Zn}$ not only depend on the total amount of nutrients present in the soil at a particular time but is also controlled by physico-chemical properties like: soil texture, organic carbon and calcium carbonate, cation exchange capacity, $\mathrm{pH}$ and electrical conductivity of soil (Bell and Dell, 2008). Keeping these facts in view, the present investigation was undertaken to study of relationship between soil $\mathrm{Zn}$ with soil properties which influences its availability to crop plants.

\section{Materials and Methods}

\section{Description of the study area}

For studying the different physico-chemical properties including soil Zn, surface soil samples $(0-15 \mathrm{~cm})$ from eleven (11) rice growing fields situated in three different agroclimatic zones of West Bengal were collected for a greenhouse experiment. The soils were collected from five different districts of West Bengal covering 11 blocks. Description of the soil collection sites are given in Table 1. Representative soil samples were collected from each of the above eleven blocks for measuring the different soil properties using standard protocols.

\section{Soil analysis}

Soil $\mathrm{pH}$ was measured in 1:2.5 soil water suspension using glass electrode $\mathrm{pH}$ meter (Jackson (1973). Electrical conductivity was measured in 1:2.5 soil water supernatant solution with the help of conductivity bridge (Jackson, 1973). The organic carbon was determined by rapid titration method (Walkley and Black, 1934) and clay content of the soils was determined through mechanical analysis by hydrometer method (Black, 1965). Determination of cation exchange capacity (CEC) of the soils was done by using the procedure given by Schollenberger and Simons (1945) Amorphous manganese and aluminium oxides was determined by the procedure given by McKeague and Day (1966). The available $\mathrm{Zn}$ in soil samples were extracted with DTPA $(0.005$ M DTPA + 0.01 $\mathrm{M} \mathrm{CaCl}_{2}+0.1 \mathrm{M}$ TEA, $\mathrm{pH}$ 7.3) as per the method described by Lindsay and Norvell (1978) and the concentration of $\mathrm{Zn}$ in the DTPA-extract was determined using atomic absorption spectrophotometer.

\section{Results and Discussion}

The range and mean values of analyzed soil properties viz $\mathrm{pH}$, organic carbon, E.C, amorphous $\mathrm{Al}$ and $\mathrm{Mn}$ oxides, $\mathrm{CEC}$ and clay and soil available $\mathrm{Zn}$ is given in Table 2 . The results in Table 2 shows that the $\mathrm{pH}$ of the soil ranges from 5.14-7.81, the organic carbon content ranged from $0.65-2.12$ per cent with a mean value of 1.30 per cent, E.C values ranges from $0.08-0.24 \mathrm{dSm}^{-1}$, the amorphous $\mathrm{Al}$ and Mn oxides ranges from 3.55-6.84 and $0.47-0.75 \mathrm{~g} \mathrm{~kg}^{-1}$ respectively. The mean value of amorphous $\mathrm{Al}$ and $\mathrm{Mn}$ oxides was 5.44 and $0.63 \mathrm{~g} \mathrm{~kg}^{-1}$ respectively. The CEC of the soil ranged from $6.51-21.23 \mathrm{meq} 100 \mathrm{~g}^{-1}$ of soil with a mean value of $13.50 \mathrm{meq} 100 \mathrm{~g}^{-1}$ of soil while clay content ranged between 17.6842.29 per cent with a mean value of 29.55 per cent. The soil available $\mathrm{Zn}$ value ranged from $0.55-1.92 \mathrm{mg} \mathrm{kg}^{-1}$ with mean value of $1.08 \mathrm{mg}$ $\mathrm{kg}^{-1}$.

Correlation between extractable $\mathrm{Zn}$ cations and soil characteristics showed dependence of available soil $\mathrm{Zn}$ on soil organic carbon, clay, CEC etc. From the results in Table 3 we observe that available $\mathrm{Zn}$ showed significant negative correlations with $\mathrm{pH}$ but positive correlations with organic carbon $(\mathrm{r}=0.722 *)$, EC $(r=0.542)$, cation exchange capacity 
$(0.524 *)$ and clay content $(r=0.249 *)$ of the soils. The availability of zinc increased significantly with increase in organic carbon because zinc forms soluble complexes with soil organic matter component. Sharma et al., in 2003 also noted positive correlations of soil $\mathrm{Zn}$ and organic carbon. Sidhu and Sharma (2010) also reported that the available micronutrients including $\mathrm{Zn}$ increased with increase in organic carbon. Yadav and Meena (2009) reported that the availability of $\mathrm{Zn}$ increased significantly with increase in clay $(\mathrm{r}=+0.597 * *)$, organic carbon $(\mathrm{r}=+0.896 * *)$, $\mathrm{EC}\left(\mathrm{r}=+0.305^{*}\right)$ and CEC $\left(\mathrm{r}=+0.527^{* *}\right)$. On the other hand, Mathur et al., (2006) also reported that the DTPA-extractable zinc was significantly and positively correlated with organic $\mathrm{C}\left(\mathrm{r}=+0.738^{* *}\right)$, CEC $\left(\mathrm{r}=+0.875^{* *}\right)$ and clay content $\left(\mathrm{r}=+0.385^{* *}\right)$. The amorphous Al-oxides and Mn oxides content were negatively correlated with extractable soil $\mathrm{Zn}$ indicating a decreased availability of
$\mathrm{Zn}$ with increased concentration of $\mathrm{Al}(\mathrm{r}=-$ $0.317)$ and $\mathrm{Mn}(\mathrm{r}=-0.084)$.

On the other hand, the availability of zinc reducing significantly with an increase in $\mathrm{pH}$ $\left(\mathrm{r}=-0.714^{*}\right)$ of soil is further concluded by many other studies. Widespread zinc deficiency problems in Indo-Gangetic plain are mostly due to the high soil $\mathrm{pH}$ both in Pakistan and India (Qadir, 2002). Havlin and Soltanpour (1981) also reported decrease in extractable zinc with increase in $\mathrm{pH}$ of soil and further explained that activity of zinc reduced 100 times with increase in one unit of $\mathrm{pH}$ from 6.2 to 7.2. In addition higher $\mathrm{pH}$ and $\mathrm{CaCO}_{3}$ content results in insoluble $\mathrm{Zn}$ compounds such as $\mathrm{Zn}(\mathrm{OH}) 2$ and $\mathrm{ZnCO}_{3}$ which can reduce the availability of zinc. The findings of the present investigation was also confirmed by the results of Singh, 2006 and Mehra, 2007.

Table.1 Description of the sampling sites

\begin{tabular}{|c|c|c|c|c|c|}
\hline \multirow{2}{*}{$\begin{array}{l}\text { Agro- } \\
\text { climatic } \\
\text { zones }\end{array}$} & \multirow[t]{2}{*}{ Districts } & \multirow[t]{2}{*}{ Blocks } & \multirow[t]{2}{*}{ Sites } & \multicolumn{2}{|c|}{ GPS location } \\
\hline & & & & Latitude & Longitude \\
\hline \multirow{2}{*}{$\begin{array}{l}\text { Coastal } \\
\text { saline Zone }\end{array}$} & \multirow{2}{*}{$\begin{array}{l}\text { S-24 } \\
\text { Parganas }\end{array}$} & Sonarpur & Kalikapur & $22^{\circ} 29^{\prime} 611^{\prime \prime}$ & $88^{\circ} 27^{\prime} 182^{\prime \prime}$ \\
\hline & & Canning- I & Amrabaria & $22^{\circ} 18^{\prime} 937^{\prime \prime}$ & $88^{\circ} 38^{\prime} 725^{\prime \prime}$ \\
\hline \multirow{6}{*}{$\begin{array}{l}\text { Gangetic } \\
\text { Alluvial } \\
\text { Zone }\end{array}$} & \multirow[t]{2}{*}{ Nadia } & Haringhata & Mitrapur & $22^{\circ} 57^{\prime} 096^{\prime \prime}$ & $88^{\circ} 35^{\prime} 38^{\prime \prime}$ \\
\hline & & Ranaghat- I & Radhanagar & $23^{\circ} 13^{\prime} 449^{\prime \prime}$ & $88^{\circ} 33^{\prime} 525^{\prime \prime}$ \\
\hline & \multirow[t]{2}{*}{ Burdwan } & Burdwan-I & Nerodighi & $23^{\circ} 20^{\prime} 996^{\prime \prime}$ & $87^{\circ} 02^{\prime} 367^{\prime \prime}$ \\
\hline & & Memari- II & Dhunui & $23^{\circ} 15^{\prime} 746^{\prime \prime}$ & $88^{\circ} 07^{\prime} 934^{\prime \prime}$ \\
\hline & \multirow[t]{2}{*}{ Hoogly } & Bolagarh & Sherpur & $23^{\circ} 02^{\prime} 10^{\prime \prime}$ & $88^{\circ} 25^{\prime} 544^{\prime \prime}$ \\
\hline & & Pandua & Berui & $23^{\circ} 06^{\prime} 717^{\prime \prime}$ & $88^{\circ} 21^{\prime} 025^{\prime \prime}$ \\
\hline \multirow{3}{*}{$\begin{array}{l}\text { Undulating } \\
\text { Red and } \\
\text { Laterite } \\
\text { zone }\end{array}$} & \multirow[t]{3}{*}{ Bankura } & Kotulpur & Muidara & $22^{\circ} 59^{\prime} 938^{\prime \prime}$ & $87^{\circ} 35^{\prime} 799^{\prime \prime}$ \\
\hline & & Jaipur & Demodarbati & $23^{\circ} 2^{\prime} 563^{\prime \prime}$ & $87^{\circ} 31^{\prime} 821^{\prime \prime}$ \\
\hline & & Onda & Rajagram & $23^{\circ} 7^{\prime} 633^{\prime \prime}$ & $87^{\circ} 13^{\prime} 369^{\prime \prime}$ \\
\hline
\end{tabular}


Table.2 Some important properties of the experimental soils

\begin{tabular}{|l|c|l|c|l|c|c|c|c|}
\hline Site & Soil Zn & $\mathbf{p H}$ & $\begin{array}{l}\text { Oxidisable } \\
\text { carbon }\end{array}$ & $\mathbf{E C}$ & $\begin{array}{l}\text { Al- } \\
\text { oxides }\end{array}$ & $\begin{array}{l}\text { Mn } \\
\text { oxides }\end{array}$ & CEC & Clay \\
\cline { 2 - 9 } & $\mathrm{mg} \mathrm{kg}^{-1}$ & & $\%$ & $\mathrm{dS} \mathrm{m}^{-1}$ & $\mathrm{~g} \mathrm{~kg}^{-1}$ & $\mathrm{~g} \mathrm{~kg}^{-1}$ & $\mathrm{meq} 100 \mathrm{~g}^{-1}$ & $(\%)$ \\
\hline Kalikapur & 1.25 & 5.43 & 1.23 & 0.18 & 4.02 & 0.59 & 14.34 & 29.09 \\
\hline Ambrabaria & 1.16 & 6.88 & 1.04 & 0.12 & 5.96 & 0.61 & 7.88 & 18.51 \\
\hline Mitrapur & 1.92 & 5.76 & 2.12 & 0.16 & 4.92 & 0.69 & 21.23 & 32.67 \\
\hline Radhanagar & 1.87 & 5.14 & 1.91 & 0.24 & 4.41 & 0.67 & 18.72 & 29.86 \\
\hline Dhunui & 0.67 & 6.25 & 1.76 & 0.13 & 3.55 & 0.55 & 12.22 & 40.95 \\
\hline Nerodighi & 0.58 & 7.81 & 1.19 & 0.15 & 6.84 & 0.75 & 19.44 & 28.92 \\
\hline Sherpur & 1.58 & 5.87 & 1.53 & 0.19 & 6.13 & 0.47 & 15.56 & 42.29 \\
\hline Berui & 0.55 & 6.11 & 0.93 & 0.17 & 5.38 & 0.55 & 6.51 & 27.71 \\
\hline Muidara & 0.81 & 7.24 & 0.65 & 0.10 & 6.37 & 0.61 & 9.21 & 17.68 \\
\hline Rajagram & 0.63 & 7.16 & 0.81 & 0.08 & 6.31 & 0.70 & 15.79 & 20.59 \\
\hline Demodarbati & 0.88 & 6.76 & 1.13 & 0.21 & 5.95 & 0.73 & 7.59 & 36.78 \\
\hline Range & $0.55-$ & $5.14-$ & $0.65-2.12$ & $0.08-$ & $3.55-$ & $0.47-$ & $6.51-21.23$ & $17.68-$ \\
\hline Mean & 1.92 & 7.81 & & 0.24 & 6.84 & 0.75 & & 42.29 \\
\hline & 1.08 & 6.40 & 1.30 & 0.16 & 5.44 & 0.63 & 13.50 & 29.55 \\
\hline
\end{tabular}

Table.3 Relationship between zinc concentration $\left(\mathrm{mg} \mathrm{kg}^{-1}\right)$ and physico-chemical properties of the initial soils

\begin{tabular}{|l|l|l|l|l|l|l|l|l|}
\hline & Soil Zn & pH & OC & EC & Al & Mn & CEC & Clay \\
\hline Soil Zn & 1.000 & $-0.714^{*}$ & $0.722^{*}$ & 0.542 & -0.317 & -0.084 & $0.524^{*}$ & $0.249^{*}$ \\
\hline pH & & 1.000 & $-0.653^{*}$ & $-0.655^{*}$ & $-0.759^{* *}$ & 0.417 & 0.221 & -0.433 \\
\hline OC & & & 1.000 & 0.524 & $-0.603^{*}$ & -0.034 & $0.632^{*}$ & $0.645^{*}$ \\
\hline EC & & & & 1.000 & -0.329 & -0.015 & 0.165 & 0.569 \\
\hline Al & & & & & 1.000 & 0.302 & -0.107 & -0.397 \\
\hline Mn & & & & & & 1.000 & 0.323 & -0.290 \\
\hline CEC & & & & & & 1.000 & 0.221 \\
\hline Clay & & & & & & & 1.000 \\
\hline * Correlation is significant at the 0.05 level (2-tailed). & & & \\
\hline
\end{tabular}

The result of this study is backed by many more similar findings as shown by Sharma et al., 2004 who reported that the content of $\mathrm{Zn}$ increased with an increase in clay, CEC and organic $\mathrm{C}$ content but decreased with increasing $\mathrm{pH}$. Similar results were also confirmed in which the DTPA-extractable Zn showed significant positive correlation with organic carbon (Jassal et al., 2014). In another study by Tundup and Akbar 2014, DTPA extractable $\mathrm{Zn}$ gave negative significant correlation with soil $\mathrm{pH}$ but was positively and significantly correlated with organic carbon and showed positive correlations with clay. Katyal and Sharma 1991, Sharma et al., 1992, Ghosh et al., 1993 further concluded similar findings. The soil samples were collected from different agro climatic zones of the state showing variable soil properties and concentration of soil $\mathrm{Zn}$ however showed similar relationships with the soil properties controlling the availability of $\mathrm{Zn}$ in such soils 
irrespective of the site of soil sample collection for the above study.

The results of the studied soils indicated that the soil properties $\mathrm{pH}$, EC organic carbon, CEC, clay content etc are the main characteristics playing major role in controlling the availability of $\mathrm{Zn}$. Available $\mathrm{Zn}$ showed significant negative correlations with $\mathrm{pH}\left(\mathrm{r}=-0.714^{*}\right)$ but positive correlations with organic carbon $\left(\mathrm{r}=0.722^{*}\right), \mathrm{EC}(\mathrm{r}=$ $0.542)$, cation exchange capacity $(\mathrm{r}=0.524 *)$ and clay content $\left(\mathrm{r}=0.249^{*}\right)$ of the soils.

\section{References}

Alloway, B.J. 2004. Zinc in soils and crop nutrition. Brussels, Belgium: International Zinc Association. http://www.zinccrops.org/Crops/Alloway-PDF

Alloway, B.J. 2008. Zinc in soils and crop nutrition. International Zinc Association, Brussels, 330 Belgium. pp. 1-135.

Anonymous, 1998. Micronutrients in Agriculture: Pakistan Perspective; National Fertilizer Development Center: Islamabad, Pakistan. antidotale Retz., under salt stress. Pak. J. Bot., 38: 16611669.

Bell, R.W. and Dell, B. 2008. Micronutrients for Sustainable Food, Feed, Fibre and Bioenergy Production. First edition, IFA, Paris, France (www.fertilizer.org).

Black C.A. Methods of Soil Analysis. Part-II. Agronomy Series. No. 9, American Society Agronomy, Inc., Madison, Wisconsin. 1965

Cakmak, I. 1998. Selection and characterization of cereal genotypes with high zinc efficiency and evaluation of bioavailability of zinc in wheat for the Central Anatolia Region; Science for Stability Programme, Cukurova University: Adana Turkey, pp.171.

Cakmak, I. 2002. Plant nutrition research priorities to meet human needs for food in 352 sustainable ways. Plant and Soil, 247: 3 -24.
Dong, Y., Ogawa, T., Lin, D., Koh, H.J., Kamiunten, H., Matsuo, M. And Cheng, S. 2006. Molecular mapping of quantitative trait loci for zinc toxicity tolerance in rice seedling (Oryza sativa L). Field Crop Research; 95:420425.

Havlin, I. L. and P. N. Soltanpur. 1981. Evaluation of $\mathrm{NH}_{4} \mathrm{HCO}_{3}$-DTPA soil test for iron and zinc. Soil Sci. Soc. Am. 45: 70-75.

Jackson, M.L. Soil chemical analysis. Prentice Hall of India Pvt. Ltd., New Delhi. 1973

Jackson, T.L., Hay, J. and Moore, D.P. 1967. The effect of $\mathrm{Zn}$ on yield and chemical composition of sweet corn in the Willamette Valley. American Society of Horticultural Science; 91: 462-471.

Katyal, J.E. and Sharma, B.D. 1991. DTPA extractable and total $\mathrm{Zn}, \mathrm{Cu}, \mathrm{Mn}$ and $\mathrm{Fe}$ in Indian soils and their association with some soil properties. Geoderma, 49: 165179.

Lindsay, W.L. and Norvell, W.A. 1978. Development of a DTPA soil test for zinc, iron, manganese and copper. Soil Science Society of America Journal; 42: 421-428.

Mathur, G. M., Deo, R. and Yadav, B. S. 2006. Status of zinc in irrigated north-west plain soils of Rajasthan. Journal of the Indian Society of Soil Science, 54 (3): 359-361.

McKeague, J.A. and Day, J.H. 1966. Dithinite and oxalate extractable $\mathrm{Fe}$ and $\mathrm{Al}$ as aids in differenting various classes of soils. Canadian Journal of Soil Science; 46: 1322.

Mehra, R.K. and Jat, J.R. 2007. To delineate the area of sufficiency and deficiency of micronutrients and their relationship with soil properties of Mokala soil series. M.Sc. (Ag.) Thesis, RAU, Bikaner.

Mortvedt, J. J., Cox, F. R., Shuman L. M. and Welch, R. M. 1991. In: J. J. Mortvedt, F. R. Cox, L. M. Shuman and R. M. Welch (eds.), Micronutrients in Agriculture, 2nd edition. Soil Sci. Soc. Am.: Madison, WI.

Pati, R. and Mukhopadhyay, D. 2011. Distribution of cationic micronutrients in some acid soils of West Bengal. Journal 
of Indian Society Soil Science 59, 125133.

Qadir, M., I. Ahmad and A. M. Ranjha. 1988. Response of wet land rice to copper and zinc in the presence of NPK. Pak. J. Agri. Sci. 55: 485-486.

Rautaray, S.K., Ghosh, B.C. and Mittra B.N. 2003. Effect of fly ash, organic wastes and chemical fertilizers on yield, nutrient uptake, heavy metal content and residual fertility in a rice-mustard cropping sequence under acid lateritic soils. Bioresource Technology; 90: 275-283.

Schollenberger, C.J. and Simon, R.H. 1945 Determination of exchange capacity and exchangeable bases in soil ammonium acetate method. Soil Science; 59: 13-24.

Sharma, B. D., and H. S. Jassal. 2013. Study of a toposequence for variability in micronutrients from the moist subhumid Siwalik agro-ecological subregion of Punjab. Archives of Agronomy and Soil Science; 59: 573-91.

Sharma, B. D., Arora, H., Kumar, R. and Nayyar, V. K. 2004. Relationships between soil characteristics and total and DTPA-extractable micronutrients in Inceptisols of Punjab. Communications in Soil Science and Plant Analysis; 35 (5 \& 6), $799-818$.

Sharma, R. P., Singh, M. and Sharma, J. P. 2003. Correlation studies on micronutrients vis-à-vis soil properties in some soils of Nagaur district in semi-arid region of Rajasthan. J. Indian Soc. Soil Sci., 51 (4): 522-527.

Sharma, S.S. 1994. Characterization and classification of soils across a toposequence over basaltic terrain in humid southern Rajasthan M.Sc. (Ag.) Thesis, R.A.U., Bikaner, Campus, Udaipur.

Sidhu, G. S. and Sharma, B. D. 2010. Diethylenetriaminepenta acetic AcidExtractable Micronutrients Status in Soil under a Rice-Wheat System and Their Relationship with Soil Properties in Different Agro-climatic Zones of IndoGangetic Plains of India. Communications in Soil Science and Plant Analysis; 41 (1): 29 - 51.

Singh, B.K. 2006. Available micronutrient status and their relationship with soil properties of Sangaria Tehsil of Hanumangarh District (Rajasthan). M.Sc. (Ag.) Thesis, RAU, Bikaner.

Tandon, H. L. S. 1995. Micronutrients in Soils, Crops, and Fertilizers. Fertilizer Development and Consultation Organization: New Delhi, India.

Tundup P and Akbar A. 2014 Distribution of micronutrient cations $(\mathrm{Zn}, \mathrm{Cu}, \mathrm{Mn}, \mathrm{Fe})$ and their relationship with soil properties of saffron growing soils of district Kishtwar in J\&K. An Asian Journal of Soil Science; 9(1): 59-62.

Walkley, A. and Black, I.A. 1934. An examination of Degtjareff method for determining soil organic matter and a proposed modification of the chromic acid titration method. Soil Science; 37: 29-37.

Yadav, R.L. and Meena, M.C. 2009. Available micronutrient status and their relationship with soil properties of Degana soil series of Rajasthan. Journal of Indian Society Soil Science 57, 90-92.

\section{How to cite this article:}

Umalaxmi Thingujam, Dipa Kundu, Rubina Khanam, Sudeshna Mondal and Hazra, G.C. 2019. Soil Available Zinc and Its Relationship with Soil Properties in Rice Soils of West Bengal, India. Int.J.Curr.Microbiol.App.Sci. 8(08): 486-491.

doi: https://doi.org/10.20546/ijcmas.2019.808.056 